\title{
HMGCR wt Allele
}

National Cancer Institute

\section{Source}

National Cancer Institute. HMGCR wt Allele. NCI Thesaurus. Code C60878.

Human HMGCR wild-type allele is located within $5 q 13.3-q 14$ and is approximately $25 \mathrm{~kb}$ in length. This allele, which encodes 3-hydroxy-3-methylglutaryl-coenzyme A reductase protein, plays a role in the regulation of cholesterol biosynthesis. 